\title{
Algılanan Güç Kaynakları ile Örgütsel Sinizm Boyutları İlişkisi: Türk Savunma Sanayii'nde Bir Araştırma \\ (Relationship Between The Perceived Power Sources Organizational Cynicism Dimensions of Employees: A Study in Turkish Defence Industry)
}

\section{Deniz ERDİK YILDIRIM iD a , Şule ERDEM TUZLUKAYA (iD $b$}

a Atılım Üniversitesi, Sosyal Bilimler Enstitüsü,İşletme Yüksek Lisans Programı, Ankara, Türkiye. denizerdik@gmail.com

b Atılım Üniversitesi, İşletme Fakültesi, İşletme Bölümü, Ankara, Türkiye. sule.tuzlukaya@atilim.edu.tr

\begin{tabular}{|c|c|}
\hline MAKALE BİLGİsİ & ÖZET \\
\hline Anahtar Kelimeler: & Amaç - Türk Savunma Sanayii'nde faaliyet gösteren Kamu Kurum Kuruluşları ile özel sektör \\
\hline Algilanan güç & firmalarının algıladıkları güç kaynakları ile örgütsel sinizmin boyutları arasındaki ilişkinin ortaya \\
\hline $\mathrm{G}$ & konmasidir. \\
\hline Örgütsel sinizm boyutları & $\begin{array}{l}\text { Yöntem - Araştırmada nicel araştırma yöntemi kullanılarak, anket yöntemi ile veriler elde } \\
\text { edilmiştir. Araştırmanın örneklemini, Türk Savunma Sanayiinde faaliyet gösteren Kamu Kurum }\end{array}$ \\
\hline Türk Savunma Sanayii & $\begin{array}{l}\text { ve Kuruluşları ile özel sektörde faaliyet gösteren örgütlerin çalsşanları oluşturmaktadır. Çalışmada } \\
\text { parametrik olmayan istatistiksel yöntemler kullanılmıştır. İki bağımsız sayısal değişken arasındaki }\end{array}$ \\
\hline Gönderilme Tarihi 5 Temmuz & ilişkiler ise Spearman's Rho korelasyon katsayısı ile yorumlanmıştır. \\
\hline $\begin{array}{l}2019 \\
\text { Revizyon Tarihi } 16 \text { Eylül } 2019 \\
\text { Kabul Tarihi } 20 \text { Eylül } 2019\end{array}$ & $\begin{array}{l}\text { Bulgular - Araştırmanın bulgularında, ödüllendirme, uzmanlık ve yasal güç kaynaklarının sinik } \\
\text { tutumdan uzaklaştıran faktörler olduğu saptanmış, ancak karizmatik güç kaynağı ile bilişsel, } \\
\text { duyuşsal ve davranışsal boyut arasında herhangi bir ilişki saptanmamıştır. Zorlayıcı güç } \\
\text { kaynağında ise güç kullanımı arttıkça çalışan sinik tutum seviyesinin arttığı sonucuna ulaşılmıştır. }\end{array}$ \\
\hline $\begin{array}{l}\text { Makale Kategorisi: } \\
\text { Araştırma Makalesi }\end{array}$ & $\begin{array}{l}\text { Tartışma - Çalışmanın en önemli katkısı, alanyazından farklı olarak Türk Savunma Sanayii } \\
\text { özelinde gerçekleştirilmesidir. Buna göre, algılanan güç kaynakları ile örgütsel sinizm arasında } \\
\text { ilişkinin varlığı literatür ile benzerlik göstermekte ancak ters yönlü bir etkileşim bulunmaktadır. }\end{array}$ \\
\hline
\end{tabular}

\begin{tabular}{|c|c|}
\hline ARTICLE INFO & ABSTRACT \\
\hline $\begin{array}{l}\text { Keywords: } \\
\text { Perceived power }\end{array}$ & $\begin{array}{l}\text { Purpose - The aim of this study is reveal the relationship between power sources and } \\
\text { organizational cynicism dimensions of public institution organizations and private sector } \\
\text { companies operating in Turkish Defense Industry. }\end{array}$ \\
\hline $\begin{array}{l}\text { Organizational Cynicism } \\
\text { Dimensions } \\
\text { Turkish Defence Industry }\end{array}$ & $\begin{array}{l}\text { Design/Methodology/approach - A quantitative approach is carried out and a survey is used for } \\
\text { data collection. The sample of the study consisted of defence industry employees. Nonparametric } \\
\text { statistical methods were used in the study. The relationships between two independent variables } \\
\text { were interpreted with Spearman's Rho correlation coefficient. }\end{array}$ \\
\hline $\begin{array}{l}\text { Received } 5 \text { July } 2019 \\
\text { Revised } 16 \text { September } 2019 \\
\text { Accepted } 20 \text { September } 2019\end{array}$ & $\begin{array}{l}\text { Findings - In the findings of the research, it was determined that reward, expert and legitimate } \\
\text { power sources were factors that removed cynical attitude from workers' perception. However, } \\
\text { results showed that there is no relation between the cognitive, affective and behavioural } \\
\text { dimensions and referent power source. In terms of coercive power source, it is found that, as the } \\
\text { use of power increases, workers cynic attitude level is also increased. }\end{array}$ \\
\hline $\begin{array}{l}\text { Article Classification: } \\
\text { Research Article }\end{array}$ & $\begin{array}{l}\text { Discussion - The most important contribution of the study is that it is realized in Turkish Defense } \\
\text { Industry. Accordingly, the existence of the relationship between perceived power sources and } \\
\text { organizational cynicism is similar to the literature but there is an inverse interaction. }\end{array}$ \\
\hline
\end{tabular}




\section{Erdik Yıldırım - Ş. Erdem Tuzlukaya 11/3 (2019) 2257-2272}

\section{GİRIŞ}

Örgütlerin varlıklarını sürdürebilmeleri ve hedeflerine ulaşmaları için insan kaynağının önemi giderek artmaktadır (Guerci vd, 2015; Guthrie, 2009; Kalağan, 2009). Güç ve güç kaynakları örgütsel anlamda çalışanın tutumunu şekillendiren bir olgu iken, sinizm açısından ele alındığında, örgüt bağlamında sinik tutumu etkileyen unsurlar bulunmaktadır. Yazında, güç ve sinizm arasındaki ilişkiyi ele alan araştırmalar ağırlıklı eğitim sektörüne odaklanmakta (Altınkurt vd, 2014; Hoşgörür, 2016; Doğan vd, 2014), farklı bağlamsal koşullara dair sonuçlara halen ihtiyaç bulunmaktadır. Yönetim alanında, örgütlerde çalışanların algıladıkları güç kaynakları ile örgütsel sinizm arasındaki ilişki üzerine kısıtlı sayıda çalışma bulunmaktadır. Türk Savunma Sanayi sektörüne yönelik bir çalışmaya ise rastlanmamıştır. Bu çalışmanın amacı, savunma sektöründe çalışanların algıladıkları güç kaynakları ile örgütsel sinizm boyutları arasında bir ilişki olup olmadığının ortaya konmasıdır.

$\mathrm{Bu}$ doğrultuda çalışmanın birinci bölümünde, örgütsel güç konusu ve örgütsel gücün kaynakları ele alınmaktadır. İkinci bölümde örgütsel sinizm kavramı, öncülleri ve sonuçları tartışılmaktadır. Üçüncü bölümde ise bu çalışmanın konusunu oluşturan örgütsel güç kaynakları ile örgütsel sinizm boyutları arasındaki ilişkinin kurgulanması ve hipotezler yer almaktadır. Dördüncü bölümde çalışmanın yöntemi ile araştırmanın bulguları ve sonuçlara dair çıkarım ve tartışmalara yer almaktadır. Sonuç bölümü ise, sonuçların tartışılması, gelecek araştırmalar için öneriler ve araştırmanın kısıtlarına dair bilgi içermektedir.

\section{Güç ve güç kaynakları}

Güç kavramına dair paylaşılan ortak bir tanım olmamakla birlikte, güç bir kişinin kendi düşüncesi doğrultusunda başka bir kişiyi etkileyerek, o kişi, olay veya durumda istediği değişiklikleri gerçekleştirebilme yeteneği olarak tanımlanmaktadır (Paulsen, 2016; Anderson vd, 2012; Brass, 2017; Paulsen, 2016). Çeşitli araştırmalarda güç, sosyal ilişkideki aktörün direncine rağmen kendi iradesini yerine getirecek bir konumda olma olasılığı (Baldwin, 1978); kişinin başkalarını etkileme becerisi (Aydın ve Çoşkun, 2007); değişimi gerçekleştirme veya sonuçları etkileme için içsel kapasite (Smith, 2010) ve değerli kaynakların kontrolünü sağlayan bir konum olarak ele alınmaktadır (Emerson 1962; Perrow 1970; Kipnis 1972; Burt 1992; Fiske 1993; Galinsky vd, 2003).

Güç kaynakları yasal güç, cezalandırma veya zorlayıcı güç, ödüllendirme gücü, karizmatik güç ve uzmanlık gücü olmak üzere beş temel başlık altında sınıflandırılmaktadır (French ve Raven, 1959). Diğer taraftan Yukl (2002) (akt. Meydan, 2010) ise, güç kaynaklarını biçimsel ve bireysel olmak üzere iki başlık altında toplamıştır. Bu çalışmada, Yukl tarafından sınıflandırılan ve French ve Raven tarafından tanımlanan güç kaynakları temel alınarak araştırma yürütülmüştür.

\subsection{Biçimsel (pozisyon) güç kaynakları}

Biçimsel güç kaynakları, kişinin örgüt içerisindeki pozisyonu ile sınırlıdır. Pozisyonun beraberinde getirdiği güç yasal, zorlayıcı/cezalandırıcı ve ödüllendirme (Brass, 2002) olmak üzere üç başlık olarak tanımlanmıştır. Yasal (meşru) gǚç kişiye örgüt ve/veya yasalar tarafından verilmekte, hiyerarşik yapının beraberinde getirdiği ast üst ilişkilerini şekillendirerek otoriteyi temsil etmektedir. Zorlayıcı (cezalandırıcı) güç, ceza ve baskıya dayalıdır ve güç uygulanan kişinin sözkonusu baskıyı hissettiği sürece varlığını devam ettirir (French ve Raven, 1959). Zorlayıcı güç kullanımına çalışan, emir veya talebi yerine getirmeyi reddetmek; mazeretler üretmek, iş yavaşlatmak; işi sabote etmeye çalışmak benzeri tepkiler verebilir (Sığrı ve Gürbüz, 2015; Karakostas ve Zizzo, 2016). Son olarak, ödüllendirme gücü ise, çalışan başarısının veya gösterdiği çabanın takdiri olarak değerlendirilmektedir.

\subsection{Bireysel güç kaynakları}

Bireysel güç kaynakları, karizmatik ve uzmanlık gücü olmak üzere iki başlık olarak tanımlanmıştır (Meydan ve Polat, 2010). Karizma kelime itibariyle bireyin kişiliğinin olağanüstü, mucizevi olarak tanımlanan ya da istisna olarak kabul edilen özelliğe sahip olmasıdır. Bu bağlamda karizmatik güu̧, kişisel özelliklere dayanır, doğuştan gelen ve zamanla şekillenen davranışlarla bütünlük sağlar, aynı zamanda ilgili kişiye karşı güven duygusu yaratarak, bağlılığı da güçlendirmektedir. Diğer bir bireysel güç kaynağı olarak uzmanlık gücü, bireyin uzmanlığının beraberinde getirdiği güç kaynağıdır ve deneyimlere 


\section{Erdik Yıldırım - Ş. Erdem Tuzlukaya 11/3 (2019) 2257-2272}

dayanmaktadır. Örgütlerde çalışanların bulunduğu pozisyonun getirisi olan güç kaynaklarının (yasal güç, zorlayıcı güç ve ödüllendirme gücü) aksine kişinin uzmanlığına duyulan takdir ve saygı ile kazanılmaktadır.

\section{2. Örgütsel sinizm}

Sinizm felsefe temellerine dayanmakla birlikte, din, politik bilimler, sosyoloji, yönetim ve psikoloji gibi disiplinlerarası çalışılmaktadır (Brandes, 1997; Kalağan ve Güzeller, 2010). Sinizm temelinde güvensizlik, kuşku, karamsarlık barındıran, bazı araştırmacılara göre bir kişilik özelliği bazılarına göre ise tutumdan ibarettir (Abraham, 2000). Bir kişiye, bir gruba, ideolojiye, sosyal geleneğe ya da örgütlere karşı hayal kırıklığı, hüsran gibi olumsuz duygular ile ya da tüm bunların güvensizliğiyle oluşan genel ve özel bir tutum olarak tanımlanan sinizm (Andersson, 1996), kişilerin kendi çıkarlarını korumak veya arttırmak için sırf araç olarak başkalarıyla ilgilenme, işleri idame etme eğiliminde olmalarını da nitelemektedir (Tokgöz ve Yılmaz, 2008; Culter, 2000). Dolayısı ile sinizm "kişilerin ardında gizlediği bir düşüncenin var olduğu, tüm gizli yanların belirli bir amaca hizmet ettiği, toplumsal dayatmaların kişileri bir tutuma sürüklediği ve bu nedenle kişinin özünün iyilikten uzaklaşıp erdemsizliğe yöneldiği tutum" olarak tanımlanabilir (Dean vd, 1998; Mantere ve Martinsuo, 2001; Rose, 2017).

Örgütsel sinizmin temelinde örgüte yönelik olumsuz tutumlar yer alır. Kişinin çalıştığı örgütün aldığı her karar ve davranışında veya her tür yaptırımında saklı tutulan bazı çıkarların ön planda olduğ $u$ ve bu çıkarların bazı amaçlara hizmet ettiğgi düşüncesinin hâkimiyeti, tüm olumsuz düşüncelerin temelini oluşturacak ve sinik tutuma sebep olacaktır. Örgütsel eylem, karar ve usullerdeki iyiliğin ya da samimiyetin reddedilmesi (Goldner vd, 1977; Kurt, 2014; James, 2005; Dean vd. 1998), örgüte karşı olumsuz duygu besleyerek, örgütün dürüstlükten yoksun olduğuna inanmak, örgüte karşı aşağılayıcı ve eleştirel hareketlerde bulunma eğiliminde olmak üzere bilişsel, duyuşsal ve davranışsal olarak örgüte karşı geliştirilen olumsuz tutumlar ve yorumlar (Johnson ve O'Learly-Kelly, 2003; Davis ve Gardner, 2004; Blanca ve Ramona, 2016), olarak ele alınmaktadır.

\section{1. Örgütsel sinizmin boyutlar}

Örgütsel sinizmin ilk boyutu olarak değerlendirilen bilişsel boyut, Dean vd tarafından (1998) "örgütün dürüstlükten yoksun olduğu" düşüncesinin hakim olması şeklinde tanımlanmaktadır. Sözkonusu inanç kişinin önceki deneyimleri ve bilgi birikimlerinden beslenmektedir. Duygusal boyut ise, olumlu veya olumsuz hisler içeren ve duyuşsal ögeleri içerme derecesine göre kişinin tutumunda farklılık yaratan bir unsur olarak tanımlanmaktadır (Köklü, 1995). Kişide oluşan olumsuz duyguların kişinin inancı devam ettiği sürece devam edebileceği ve beraberinde sinik tutumu getirebileceği söylenebilir. Bu bağlamda çalışanın sahip olduğu duyuşsal boyuttaki sinik tutum, davranışsal boyuta dönüşmeden örgüt tarafından fark edilmesi önemlidir. Son olarak davranışsal boyut, çalışanların örgüt içinde gelecek olaylar hakkında karamsar tahminler yapma eğiliminde olmaları, örgüte karşı eleştirel yaklaşarak olumsuz inanç ve düşünceleri dile getirmeleri, örgütü yermek veya küçümser tavırda yaklaşmaları kısaca örgüte karşı inancının olmadığını sözlü veya davranışsal olarak yansıtmaları durumu olarak tanımlanmaktadır.

\section{Güç Kaynakları ile Örgütsel Sinizm Boyutları Arasındaki İlişki}

Bu bölümde, birinci bölümde yer alan güç kaynakları ile ikinci bölümde yer alan örgütsel sinizm konuları arasındaki ilişki durumunun ortaya konması amaçlanmaktadır. Ardından, araştırma evreni özelinde yapılan çalışma gereği, Türk Savunma Sanayii'ne değinilerek, hipotezler verilmektedir.

Türk Savunma Sanayii, kamu üreticilerinin çoğunluğu oluşturduğu bir sektör olmakla birlikte, elektronik ve yazılım alanlarında özel sektörden de birçok firmanın faaliyet gösterdiği bir sektördür. Çalışma alanının niteliğiyle ilintili olarak müşterisi resmi makamlar olan savunma sanayii, öncelikli yatırım alanlarına yönelik teşvik kapsamında olan ${ }^{1}$, teknolojilerin gizliliği yasal düzenlemelerle korunan ${ }^{2}$ ve nitelikli insan

${ }^{1}$ T.C. Ekonomi Bakanlığı Resmi İnternet Sayfası. 9 Mayıs 2018, (Erişim),

https://www.ekonomi.gov.tr/portal/faces/oracle/webcenter/portalapp/pages/content/htmlViewer.jspx;jsessionid=jrNFS 1kCpnqHdGuqE4IEnrDZl5TyNGLUBVqz2hxlgXe-Q0JVUFH2!-

335026037? contentId=UCM\%23dDocName\%3AEK-167551\&parentPage=yatirim\&_afrLoop=25119136370110018

2 Savunma Sanayii Güvenliği Kanunu, 5 Mayıs 2018, (Erişim), http://www.mevzuat.gov.tr/MevzuatMetin/1.5.5202.pdf 


\section{Erdik Yıldırım - Ş. Erdem Tuzlukaya 11/3 (2019) 2257-2272}

gücünün ${ }^{3}$ kritik kaynaklardan biri olduğu sektörlerden biridir (Yılmaz, 2012). Katı hiyerarşinin yerleşik olduğu Türk Savunma Sanayii, özel sektörün daha esnek yapısının olması sebebiyle biraz daha kırılarak sivil-asker ilişkisine yeni bir boyut getirmiştir. İnsan gücü odaklı olan bu sektörde, çalışan beklenti ve ihtiyaçlarının özel sektörde daha dinamik bir şekilde karşılandığı, hiyerarşinin beraberinde getirdiği disiplinin biraz daha esnek olduğu ve iç süreçlerin daha hızlı işleyerek beklentileri karşılama süresinin daha kısaldığı söylenebilir. Şeşen (2010) de savunma sanayiinde çalışanlarını, uzman personel gerektiren, yenilikçi ve yaratıcı özelliklere sahip, geniş bir sosyal ağ içerisinde birbirleri ile iletişim halinde olan bireyler olarak tanımlamaktadır.

Yöneticilerin bulundukları pozisyonun sağladığı doğal güç, yasalar tarafından verilen güç kaynağıdır. Çalışan açısından ele alındığında ise, yapıdan kaynaklı kurallar benzer biçimde yaptırımlara yansımaktadır. Yasal güç aracılığı ile otoritenin temsiline de dayalı olarak, çalışan görevi yerine getirmekte ancak itaate dayalı gerçekleşen bu eylem sonucunda performans ve işin niteliği sorunlu olabilmektedir (Yukl, 2000). Savunma sektöründe yasal güç, çalışanlar açısından katı hiyerarşik yapının beraberinde getirdiği yaptırımın gücünü temsil eder. Örgütün ve yöneticinin adil olmayan ve samimiyetten uzak yaklaşımları, örgüte ve yöneticiye dair bilişsel değerlendirmenin olumsuz olmasına, yani sinik davranışa yöneltecektir. Ayrıca itaat sözkonusu olduğunda, çalışanın kararlara düşük düzeyde katılımı, bilişsel düzeyde çalışanda örgütsel kararlara dair olumsuz inancın oluşmasına da etkili olabilir. Savunma sektörü yasal gücün önemli şekilde varolduğu bir sektör olarak kabul görmektedir. Dolayısı ile, bu sektör bağlamında, yasal güç algısı ile bilişsel sinizm boyutu arasında önemli bir ilişkinin varlığından bahsetmek olanaklıdır. Buradan hareketle, Hıa aşağıdaki gibidir:

\section{H1a: Savunma sektöründe algılanan yasal güç ile bilişsel sinizm boyutu arasında pozitif yönlü bir ilişki vardır.}

Yasal güce dair algı aynı zamanda güçlü duygusal tepkiler içermesi sebebiyle tarafsız değildir. Yöneticinin yasal gücüne dair algısı olumsuz olan çalışanlar, örgütsel ve yönetimsel kararlara dair de olumsuz duygular geliştirebilecek, çalışanların duyuşsal sinizm geliştirmesinde etkili olabilecektir. Buradan hareketle, yasal güç ile duyuşsal sinizm boyutu arasındaki ilişkiye istinaden, oluşturulan $\mathrm{H}_{1 \mathrm{~b}}$ şu şekildedir;

H1b: Savunma sektöründe algılanan yasal güç ile duyuşsal sinizm boyutu arasında pozitif yönlü bir ilişki vardır.

Örgüt içi hiyerarşinin net bir şekilde hissedildiği sektörde, çalışan tutumları da bu katı kurallara ve tanımlı sınırlara göre şekillenmektedir. Davranışa dönüşmeyen her tutumun, ilişkiler seviyesinde hissedilme oranı düşüktür. Ar-Ge temelinde yürüyen sektörel faaliyetler, katma değeri yüksek ürünlere dönüştükçe tutumların davranışsal boyuta dönmesine engel olabilmektedir. Sektörün yasal güçten beslenmesi tutumların davranışa dönüşmemesinde etkili olabilecektir. Dolayısı ile,

H1c: Savunma sektöründe algılanan yasal güç ile davranışsal sinizm boyutu arasında bir ilişki yoktur.

Yöneticilerin sahip olduğu güçlerden bir diğer ise zorlayıcı güç kaynağıdır. Savunma sanayiinde en kritik bileşen olarak gözüken Ar-Ge faaliyetleri insan gücü odaklı yürütülmekte ve zorlayıcı güç kaynağı çalışan tarafından olumlu karşılanmayan ve tepki alan bir yöntem olarak karşılanmaktadır. Sektörde çalışanların yetkinliklerinin çoğunun kritik teknolojiler üzerine olması ve bu teknolojilerin uluslararası ve/veya ulusal düzlemde yaygın olmaması, çalışanın kendisini sektörde biricik hissetmesine sebep olabilmektedir. Yöneticilerin beklentilerini karşılamayan çalışanlar üzerine uyguladığı algısını yaratan bu yöntemin, sektörde faaliyet gösteren kişiler üzerinde olumsuz etkilere neden olduğu söylenebilir. Kişinin kendisini biricik hissetmesi, zorlayıcı güç uygulandığı zaman kendisini yetersiz hissetmesine veya yöneticisinin yetersiz kaldığı algısına neden olmaktadır. Bu bakış açısıyla oluşturulan hipotez $\mathrm{H}_{2 a}$ şu şekildedir;

$H_{2 a:}$ Savunma sektöründe algılanan zorlayıcı güç ile bilişsel sinizm boyutu arasında pozitif yönlü bir ilişki vardır.

Ceza ve baskıya dayalı olarak yazında tanımlanan zorlayıcı güç, çalışan üzerinde baskı yaratmakta (Özkalp vd, 2013) ve önemli psikolojik sonuçları ortaya çıkmaktadır. Sözkonusu psikolojik sonuçlardan biri olarak çalışanda tehdit algısının oluşması gösterilebilir ki bu, yine çalışanda sinik davranışın oluşması için

\footnotetext{
${ }^{3}$ Savunma Sanayii Müsteşarlığı (SSM), Savunma, Havacılık ve Uzay Alanında Yüksek Nitelikli İnsan Kaynağını Nasıl Arttırırız?" Çalıştayı, SSM, Çankaya, Ankara, 16 Aralık 2014, s.1-26

* Süregelen düzenin korunması durumu, sürer durum. (TDK, 2018)
} 


\section{Erdik Yıldırım - Ş. Erdem Tuzlukaya 11/3 (2019) 2257-2272}

zemin hazırlamaktadır. Zorlayıcı güce dayalı olarak çalışanlar kendisini olumsuz duygulanım içinde bulabilir ve zorlayıcı gücün kaynağına dair olumsuz düşünceler -örneğin çalışanın kendisini daha yetkin görmesi, gücü kullanan kişiye saygı duymaması gibi- geliştirebilir. Bu değerlendirmeler, zorlayıcı güç algısı ile duyuşsal sinizm boyutu arasında ilişkinin varlığını işaret etmektedir. Savunma sektörü özelinde ele alındığında zorlayıcı güç kaçınılmaz olarak sektörün bir özelliği olarak karşımıza çıkmakta ve değerlendirildiğinde çalışanlar üzerinde çeşitli duygu ve duygu durum değişikliklerine neden olmaktadır. Buradan hareketle $\mathrm{H}_{2 \mathrm{~b}}$ aşağıdaki gibidir:

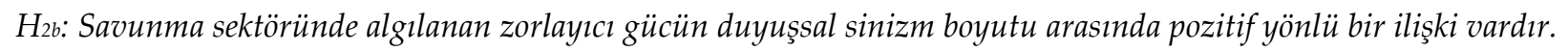

Yasal güçte detayı verilen gerekçeler sebebiyle, bilişsel ve duyuşsal boyutta gelişen sinik tutum davranışsal boyuta dönüşmemektedir. Bu çerçevede, savunma sektöründe algılanan zorlayıcı güç ile davranışsal ( $\left.\mathrm{H}_{2} c\right)$ sinizm boyutu arasinda bir ilişki yoktur.

Türkiye'de savunma sektöründe faaliyet gösteren kamu kurum ve kuruluşları, mevzuata bağlı iç işleyişlerini yürüttükleri için örgüt içi çalışanların ödüllendirilmeleri de üst yönetici seviyesinde karar verilerek gerçekleştirilir. Savunma sektöründe faaliyet gösteren özel şirketlerde, yöneticinin kararı veya üst yönetici ile görüşmesi ile çalışanın ödüllendirilmesi mümkün olabilir. Başarı sonucu çalışanın maaş artışının yapılması özel şirketlerde tercih edilen formal yöntemlerden sadece birine örnek olabilir.

Ödüllendirme gücü, yöneticinin bu gücü elinde tuttuğu süre boyunca sahip olduğu güç kaynağıdır ve zorlayıcı gücün aksi bir anlam taşımaktadır (Kelman, 1958).. Genel açıdan bakıldığında, ödüllendirme gücünün gerek kamuda gerekse özel sektörde çalışanlar üzerine etkisinin olduğu söylenebilir. Savunma sektöründe özellikle daha önce vurgulanan çalışanların kendisini biricik hissetmesi maddi ve manevi tatmini önemli kılmaktadır. Ödüllendirme gücünün varlı̆̆ı, çalışan motivasyonunu sağlar, örgütsel adalet algısını yaratır, aidiyet duygusunu güçlendirir, çalışanda olumlu düşüncelerin oluşmasına yani bilişsel boyutta çalışanın etkilenerek sinik tutumdan uzaklaşmasını sağlar. Dolayısı ile, $\mathrm{H}_{3 a}$ aşağıdaki şekilde oluşmaktadır:

Hзa: Savunma sektöründe algllanan ödüllendirme gücü ile bilişsel sinizm boyutu arasında negatif yönlü bir ilişki vardır.

Ödüllendirme gücünün varlığı, çalışanların örgüte ve yöneticilerine dair olumlu duygular geliştirmesinde etkili olabilir. Ödüllendirme gücü, çalışanın kısmi olarak subjektif değerlendirmelerden uzaklaşabilmesine, takdir edilme duygusu ile yöneticiye ve örgüte dair olumlu duyguların ortaya çıkmasına, dolayısı ile sinizmin tanımı içinde yer alan saygısızlık, öfke, aşağılama benzeri olumsuz duygu ve tepkilerden uzaklaşmasında etkili olacaktır. Bu şekliyle değerlendirildiğinde, $\mathrm{H}_{3 \mathrm{~b}}$ aşağıdaki gibidir:

Hзb: Savunma sektöründe algilanan ödüllendirme gücü ile duyuşsal sinizm boyutu arasında negatif yönlü bir ilişki vardir.

Ancak ödüllendirme gücü sektörel bazda değerlendirildiğinde, davranışsal boyutta çalışan üzerinde herhangi bir etkisinin olmaması beklenmektedir. Bu bağlamda,

(Hзc): Savunma sektöründe algilanan ödüllendirme gücü ile davranışsal sinizm boyutu arasında bir ilişki yoktur.

Örgütlerde örgütsel sinizm tutumunu etkileyen unsurlardan biri de yöneticilerin uyguladığı karizmatik güç kaynağıdır. Savunma sektörü temelini bilgiye ve Ar-Ge'ye dayandıran bir sektör olup, örgütlerarası veya örgüt içi gizlilik esas alınarak faaliyetler icra edilmektedir. Çalışanların gizliliğe riayet ederek gerçekleştirdiği faaliyetler gerek sektör özelinde gerekse örgüt içerisinde gizem yaratmakta olup, çalışan egosunu arttırdığı söylenebilir. Bass'a (akt. Doğan, 2014) göre bu yöneticinin, çok üstün inandırma, tartışma gücüne ve teknik uzmanlığa sahip olduğu, astlarında tutumsal, davranışsal ve coşkusal değişiklikler yaptığı ifade edilmektedir. Takipçilerin sinik tutuma dair inançları, karizmatik liderin bencil, kar-odaklı hedeflere odaklanacağı inancını yansıtmaktadır. Savunma sektöründe, önceki bölümlerde de üzerinde durulan uzmanlık ve eğitim seviyesi bağlamında ele alındığında, çalışanlar ile yöneticiler arasında bahsi geçen şekilde istisnai güç, uzmanlık ve/veya kalite farklılığı olup, çalışanların ve sektörel egonun olması sebebiyle herhangi bir sinizm boyutunun ortaya çıkmasının beklenmeyeceği öngörülebilir. Bu şekilde ele alındığında, karizmatik güç ile örgütsel sinizm boyutları arasında bir ilişki olduğu değerlendirilmemiş olup, oluşturulan hipotezler şu şekildedir; 


\section{Erdik Yıldırım - Ş. Erdem Tuzlukaya 11/3 (2019) 2257-2272}

H4a: Savunma sektöründe algılanan karizmatik güç kaynă̆ı ile bilişsel sinizm boyutu arasında bir ilişki yoktur.

H4b: Savunma sektöründe algılanan karizmatik güç kaynağı ile duyuşsal sinizm boyutu arasında bir iliş̧k yoktur.

H4c: Savunma sektöründe algılanan karizmatik güç kaynağı ile davranışsal sinizm boyutu arasında bir ilişki yoktur.

Sektör özelinde incelendiğinde, insan gücünün öncelikli yatırım alanlarından biri olduğu söylenebilir. Uzmanlık gücüne sahip olabilmek için yılların bilgi birikimi ve tecrübeye ihtiyaç duyulmaktadır. Son yıllarda dış bağımlılı̆̆ın azalmasına yönelik yatırımların artması, çalışan nazarında bu güce sahip kişilere karşı sadece bilişsel boyutta değerlendirme yapılmaktadır. Kişinin uzmanlık gücü, uzmanlığının beraberinde getirdiği güç kaynağıdır. Bu güç kaynağına sahip bireyler takdir ve saygı kazanmaktadır. Bu şekilde değerlendirildiğinde, çalışanların örgüte ve yöneticilere dair olumsuz değerlendirmelerden uzaklaşmaları beklenebilir. Ancak duygusal ve davranışsal boyutlarda herhangi bir etki yaratması beklenmemektedir. Bu bakış açısıyla oluşturulan hipotezler şu şekildedir;

H5a: Savunma sektöründe algılanan uzmanlık gücü ile bilişsel sinizm boyutu arasında negatif yönlü bir iliş̧ki vardır.

H5b: Savunma sektöründe algılanan uzmanlık gücü ile duyuşsal sinizm boyutu arasında bir ilişki yoktur.

H5c: Savunma sektöründe algilanan uzmanlık gücü ile davranışsal sinizm boyutu arasında bir iliş̧ki yoktur.

\section{YÖNTEM}

\section{Araștırmanın Amacı}

Bu çalışmanın amacı savunma sanayiinde çalışanların algıladıkları güç kaynakları ile örgütsel sinizm boyutları arasında bir ilişki olup olmadığının ortaya konmasıdır. Araştırmada nicel araştırma yöntemi kullanılarak, anket yöntemi ile veriler elde edilmiştir.

\section{Örneklem}

Araştırmanın evrenini, Türk Savunma Sanayiinde faaliyet gösteren Kamu Kurum ve Kuruluşları ile özel sektörde faaliyet gösteren örgütlerin çalışanları oluşturmaktadır. Savunma sanayii sektörel durumu hem de tüm çalışanlara erişilmesinin mümkün olmaması sebebiyle, örnekleme yoluna gidilmiştir. Veri toplama aşamasında amaçlı örnekleme tekniği kullanılmıştır. Internet ortamında oluşturulan anket profesyonel sosyal paylaşım platformları aracılığıyla sadece ulaşılması mümkün olabilen kitleler ile paylaşılmıştır. Sektör çalışanlarının da yer aldığı sosyal paylaşım platformunda 1401 katılımcıya ulaşılmış ve anketin geri dönüş oranı \%13,49 olmuştur. Anket verisinde yapılan incelemeler sonucunda, 10 kişinin anketinde eksik soruların olduğu ve 12 kişinin de doldurmuş olduğu anket verisinde hata (toplam çalışma süresinin sektörde çalışma süresinden az olduğu) saptanarak analizden çıkarılmıştır. Toplamda 167 kişinin anket verisinin analiz kapsamında alındığı araştırmada, araştırmaya katılan katılımcıların demografik özellikleri Tablo 1.'de yer almaktadır.

Tablo 1.Demografik Özellikler Bazında Analiz Sonuçları

\begin{tabular}{llll}
\hline & & Sayı & Yüzde \\
\hline Cinsiyete Göre Dağılımlar & Kadın & 51 & 30,5 \\
& Erkek & 116 & 69,5 \\
\hline Yaşa Göre Dağılımlar & $24-33$ Yaş & 40 & 24,0 \\
& 34-43 Yaş & 81 & 48,5 \\
& 44 Yaş ve Üzeri & 46 & 27,5 \\
\hline Eğitim Durumuna Göre Dağılımlar & Ön Lisans & 13 & 7,8 \\
& Lisans & 57 & 34,1 \\
& Yüksek Lisans & 64 & 38,3 \\
& Doktora & 32 & 19,2 \\
& Diğer & 1 & 0,6 \\
\hline Çalışma Süresine Göre Dağılımlar & 5 Yıldan Az & 20 & 12,0 \\
& 5-10 Yıl & 30 & 18,0
\end{tabular}


D. Erdik Yıldırım - Ş. Erdem Tuzlukaya 11/3 (2019) 2257-2272

\begin{tabular}{llll}
\hline & & Sayı & Yüzde \\
\hline & $11-15$ Yıl & 46 & 27,5 \\
& 15 Yı̈ Üzeri & 71 & 42,5 \\
\hline İşyeri Statüsüne Göre Dağılımlar & Kamu Kurum/Kuruluşu & 84 & 50,3 \\
& Özel Şirket & 83 & 49,7 \\
\hline Savunma Sanayindeki Görev Yıllarına & 1 Yıldan Az & 10 & 6,0 \\
Göre Dağılımlar & $1-5$ Yıl & 35 & 21,0 \\
& 6-10 Yıl & 29 & 17,4 \\
& $11-15$ Yıl & 49 & 29,3 \\
& 16 Yıldan Fazla & 44 & 26,3 \\
\hline
\end{tabular}

Demografik verilerin analiz sonuçlarına göre, katılımcıların çoğunluğunun $(69,5) \quad(N=116)$ erkek katılımclardan oluştuğu görülmektedir. Yaş aralıkları açısından incelendiğinde, 24-33 yaş aralığında \%24 $(\mathrm{N}=40), 34-43$ aralığında \%48,5 $(\mathrm{N}=81)$ ve 44 yaş ve üzerinde ise katılımcıların oranının $\% 27,5(\mathrm{~N}=46)$ olduğu görülmektedir. Eğitim durumları açısından değerlendirildiğinde, önlisans \%7,8 (N=13), lisans $\% 34,1(\mathrm{~N}=57)$, yüksek lisans \% 38,3 ( $\mathrm{N}=64)$ ve doktora \% 19,2 (N=32) oranlarında yüksek öğrenimine devam eden bir katılımcı grubu olduğu görülmektedir. Çalışma süreleri ise $\% 12(\mathrm{~N}=20)$ oranında 5 yıldan az ve \%18 ( $\mathrm{N=30)}$ oranında 5-10 yıl arasında, \% 27,5 oranında ( $\mathrm{N}=46)$ 11-15 yıl arasında ve 15 yıl ve üzeri ise $\% 42,5 \quad(\mathrm{~N}=71) \quad$ oranında olduğu görülmektedir. Katılımclların özel şirketlerde \% 49,7 (N=83) ve kamu kuruluşlarında \% 50,3 ( $\mathrm{N=84)} \mathrm{çalıştıkları} \mathrm{görülmektedir.} \mathrm{Savunma} \mathrm{sanayindeki}$ görev yılları incelendiğinde \%6 oranında ( $\mathrm{N}=10) 1$ yıldan az, \%21 oranında ( $\mathrm{N}=35)$ 1-5 yıl arasında, \%17,4 oranında (N=29) 6-10 yil arasında, \%29,3 oranında $(\mathrm{N}=49)$ 11-15 y1l arasında ve \%26,3 oranında $(\mathrm{N}=44)$ ise 16 yıldan fazladır. Çalışmaya katılanların önemli bir çoğunluğunun sektörde deneyime sahip oldukları sonucuna varılabilir.

\section{Veri Toplama Araçları}

\section{Örgütsel güç kaynă̆g ölçeğgi}

Güç kaynakları algısına ilişkin Hinkin ve Schreisheim (1989) tarafından geliştirilen ve Sığrı ve Gürbüz (2015) tarafından Türkçe'ye uyarlanan 20 maddelik örgütsel güç kaynağı ölçeği kullanılmıştır. Uygulanan Cronbach Alfa güvenirlik analizi tablo 2' de verilmektedir.

Tablo 2. Örgütsel Güç Kaynağı Ölçeği ve Alt Boyutları İçin Güvenirlikler

\begin{tabular}{lcc}
\hline & Madde Sayıs & Cronbach Alfa \\
\hline Ödüllendirme Gücü & 4 & 0,793 \\
Zorlayıcı Güç & 4 & 0,917 \\
Yasal (Meşru) Güç & 4 & 0,927 \\
Uzmanlık Gücü & 4 & 0,930 \\
Karizmatik (Beğeniye Dayalı) Güç & 4 & 0,942 \\
Örgütsel Güç Kaynağı Ölçeği & 20 & 0,862 \\
\hline
\end{tabular}

Örgütsel güç kaynağı ölçeği doğrulayıcı faktör analizi

20 madde 5 faktörden oluşan yapıyı doğrulamak için kurulan ölçüm modeli analiz edilmiştir. Analiz sonucunda modelin yeterli uyum göstermediği görülmüş ve bu nedenle model iyileştirme çalışmaları yapılmıştır. Öncelikle modifikasyon indeksleri tablosuna bakılarak modelde yapılacak olası değişiklikler için ki kare düşüş değerleri ("M.I."değerleri) incelenmiştir. En yüksek "M.I." değerinin göstermiş olduğu modifikasyon, kavramsal olarak uygun olduğu durumlarda bağlanarak model yürütülmüştür. Sonuç olarak modelin doğrulandığ1 görülmüştür. Doğrulanan ölçüm modeli şekil 1'de sunulmuştur. 




Şekil 1. Örgütsel Güç Kaynağı Ölçeğinin Ölçüm Modeli

Şekil 1'de yer alan ölçüm modeli incelendiğinde, 20 madde 5 faktör ile doğrulanan ölçüm modelinin hangi maddelerden oluştuğunu ve diğer yandan tek yönlü oklar üzerindeki yollara ait standardize regresyon katsayılarını yani başka bir deyişle faktör yüklerini görmekteyiz. Yapıda 0,600'ün altında faktör yükü olmadığı görülmüştür.

Tablo 3: Örgütsel güç kaynağı ölçeği doğrulayıcı faktör analizi uyum indeks değerleri ve kabul edilebilir uyum değerleri

\begin{tabular}{lcc}
\hline & Uyum İndeks Değerleri & Kabul Edilebilir Uyum Değerleri \\
\hline$\chi^{2} / \mathbf{s d}$ & 3,009 & $\leq 5$ \\
GFI & 0,899 & $\geq 0,850$ \\
CFI & 0,905 & $\geq 0,850$ \\
NFI & 0,865 & $\geq 0,850$ \\
TLI & 0,886 & $\geq 0,850$ \\
RMSEA & 0,071 & $\leq 0,080$ \\
SRMR & 0,009 & $\leq 0,100$ \\
\hline
\end{tabular}

$\chi^{2} / \mathrm{sd}=$ kikare / serbestlik derecesi (chi square/degres of freedom); GFI = İyilik Uyum İndeksi (Goodness Fit Index); $C F I=$ Karşılaştırmalı Uyum İndeksi (Comparative Fit Index); NFI = Normlaştırılmış Uyum İndeksi (Normed Fit Index); TLI = Tucker-Lewis Indeks; RMSEA = Tahmin Hatalarmın Ortalamasının Karekökü (Root Mean Square Error of Approximation); SRMR = Standartlaştırlmış Hata Kareleri Ortalamasının Karekökü (Standardized Root Mean Square Residual)

Tablo 3 incelendiğinde Örgütsel Güç Kaynağı Ölçeğinin doğrulayıcı faktör analizi sonuçlarının kabul edilebilir sınırlarda olduğu görülmektedir.

Örgütsel sinizm ölçeği

Örgütsel sinizme ilişkin Brandes ve diğerleri (1999) tarafından geliştirilen Kalağan (2009) tarafından Türkçe'ye uyarlanan 13 maddelik "Örgütsel Sinizm Ölçeği” kullanılmıştır. Bu ölçek; bilişsel (5 madde), 
D. Erdik Yıldırım - Ş. Erdem Tuzlukaya 11/3 (2019) 2257-2272

duyuşsal (4 madde) ve davranışsal (4 madde) olacak şekilde 3 boyuttan oluşmaktadır. Tablo 4'de ölçek ve alt boyutları için güvenirlik verilmektedir.

Tablo 4. Örgütsel Sinizm Ölçeği ve Alt Boyutları İçin Güvenirlikler

\begin{tabular}{lcc}
\hline & Madde Sayısı & Cronbach Alfa \\
\hline Bilişsel Boyut & 5 & 0,910 \\
Duyuşsal Boyut & 4 & 0,937 \\
Davranışsal Boyut & 4 & 0,832 \\
Örgütsel Sinizm Ölçeği & 13 & 0,919 \\
\hline
\end{tabular}

Örgütsel sinizm ölçeği doğrulayııı faktör analizi

13 madde 3 faktörden oluşan yapıyı doğrulamak için kurulan ölçüm modeli analiz edilmiştir. Analiz sonucunda modelin yeterli uyum göstermediği görülmüş ve bu nedenle model iyileştirme çalışmaları yapılmıştır. Öncelikle modifikasyon indeksleri tablosuna bakılarak modelde yapılacak olası değişiklikler için ki kare düşüş değerleri ("M.I."değerleri) incelenmiştir. En yüksek "M.I." değerinin göstermiş olduğu modifikasyon, kavramsal olarak uygun olduğu durumlarda bağlanarak model yürütülmüştür. Sonuç olarak modelin doğrulandığı görülmüştür. Doğrulanan ölçüm modeli aşağıda sunulmuştur.



Şekil 2. Örgütsel Sinizm Ölçeğinin Ölçüm Modeli

Şekil 2'deki ölçüm modeli incelendiğinde, 13 madde 3 faktör ile doğrulanan ölçüm modelinin hangi maddelerden oluştuğunu ve diğer yandan tek yönlü oklar üzerindeki yollara ait standardize regresyon katsayılarını yani başka bir deyişle faktör yüklerini görmekteyiz. Yapıda 0,600'ün altında faktör yükü olmadığı görülmüştür. 
D. Erdik Yıldırım - Ş. Erdem Tuzlukaya 11/3 (2019) 2257-2272

Tablo 5. Örgütsel Sinizmı Ölçeği Doğrulayıcı Faktör Analizi Uyum İndeks Değerleri ve Kabul Edilebilir Uyum Değerleri

\begin{tabular}{lcc}
\hline & Uyum İndeks Değerleri & Kabul Edilebilir Uyum Değerleri \\
\hline$\chi^{2} /$ sd & 4,177 & $\leq 5$ \\
GFI & 0,856 & $\geq 0,850$ \\
CFI & 0,894 & $\geq 0,850$ \\
NFI & 0,867 & $\geq 0,850$ \\
TLI & 0,863 & $\geq 0,850$ \\
RMSEA & 0,078 & $\leq 0,080$ \\
SRMR & 0,012 & $\leq 0,100$ \\
\hline
\end{tabular}

$\chi^{2} / \mathrm{sd}=$ kikare / serbestlik derecesi (chi square/degres of freedom); GFI = İilik Uyum Indeksi (Goodness Fit Index); $C F I=$ Karşılaştırmalı Uyum İndeksi (Comparative Fit Index); NFI = Normlaştırılmış Uyum İndeksi (Normed Fit Index); TLI = Tucker-Lewis Indeks; RMSEA = Tahmin Hatalarının Ortalamasının Karekökü (Root Mean Square Error of Approximation); SRMR = Standartlaştırlmış Hata Kareleri Ortalamasının Karekökü (Standardized Root Mean Square Residual)

Tablo 5 incelendiğinde Örgütsel Sinizm Ölçeğinin doğrulayıcı faktör analizi sonuçlarının kabul edilebilir sinırlarda olduğu görülmektedir.

\section{Veri Analizi}

Veriler IBM SPSS Statistics 23 paket programına aktarılarak analizler gerçekleştirilmiştir. Çalışmada kullanılan ölçekler ve alt boyutları için güvenirlik analizi uygulanmış ve ölçeklerin ve ilgili alt boyutlarının güvenirliklerinin yüksek olduğu görülmüştür. Analize girecek sayısal değişkenler için Kolmogorov Smirnov testi uygulanmış ve değişkenlerin normal dağılıma uyum sağlamadıkları görülmüştür. Bu nedenle çalışmada parametrik olmayan istatistiksel yöntemlerden yararlanılmıştır. İki bağımsız sayısal değişken arasındaki ilişkiler ise Spearman's Rho korelasyon katsayısı ile yorumlanmıştır. Gerçekleştirilen analizlerde \%95 güven düzeyi ve 0,05 anlamlılık düzeyinde çalışılmıştır. Tablo 6 da, ölçekler ve alt boyutları için istatistikler, güvenirlikler ve normallik verilmektedir.

Tablo 6. Ölçekler ve Alt Boyutları İçin Tanımlayıcı İstatistikler, Güvenirlikler ve Normallikler

\begin{tabular}{lcrrcc}
\hline (n=167) & Ortalama & $\begin{array}{c}\text { Standart } \\
\text { Sapma }\end{array}$ & Medyan & $\begin{array}{c}\text { Cronbach } \\
\text { Alfa }\end{array}$ & $\begin{array}{c}\text { Kolmogorov } \\
\text { Smirnov (p) }\end{array}$ \\
\hline Örgütsel Güç Kaynağ1 & 3,58 & 0,58 & 3,60 & 0,849 & 0,001 \\
Ödüllendirme Gücü & 3,50 & 0,98 & 3,75 & 0,817 & 0,000 \\
Zorlayicı Güç & 3,56 & 1,07 & 4,00 & 0,921 & 0,000 \\
Yasal (Meşru) Güç & 3,75 & 0,89 & 4,00 & 0,919 & 0,000 \\
Uzmanlık Gücü & 3,50 & 1,07 & 3,75 & 0,937 & 0,000 \\
Karizmatik (Beğeniye Dayalı) Güç & 3,62 & 1,04 & 4,00 & 0,949 & 0,000 \\
\hline Örgütsel Sinizm & 3,17 & 0,85 & 3,20 & 0,922 & 0,004 \\
Bilişsel Boyut & 3,61 & 0,94 & 3,60 & 0,906 & 0,000 \\
Duyuşsal Boyut & 2,81 & 1,21 & 2,50 & 0,947 & 0,000 \\
Davranışsal Boyut & 3,08 & 0,91 & 3,00 & 0,822 & 0,000 \\
\hline
\end{tabular}




boyutlarının güvenilir olduğu görülmektedir $(\alpha>0,700)$. Uygulanan Kolmogorov Smirnov normallik testi sonucunda tüm ölçek ve alt boyutlarının dağılımının normal dağılıma uymadığı görülmektedir $(p<0,05)$. 
D. Erdik Yıldırım - Ş. Erdem Tuzlukaya 11/3 (2019) 2257-2272

Tablo 7. Ölçekler ve Alt Boyutları Arasındaki İlişkilerin İncelenmesi

\begin{tabular}{|c|c|c|c|c|c|}
\hline & & Örgütsel Sinizm & Bilişsel & Duyuşsal & Davranışsal \\
\hline \multirow{2}{*}{ Örgütsel Güç } & $\mathrm{r}$ &,$- 178^{*}$ &,$- 204^{*}$ & $-0,135$ & $-0,043$ \\
\hline & $\mathrm{p}$ & 0,021 & 0,008 & 0,081 & 0,580 \\
\hline \multirow{2}{*}{ Ödüllendirme Gücü } & $\mathrm{r}$ &,$- 225^{*}$ &,$- 203^{*}$ &,$- 241^{*}$ & $-0,079$ \\
\hline & $\mathrm{p}$ & 0,003 & 0,008 & 0,002 & 0,311 \\
\hline \multirow{2}{*}{ Zorlayıcı Güç } & $\mathrm{r}$ & $\begin{array}{l}171^{*} \\
\end{array}$ & 0,152 & ,247 & $-0,085$ \\
\hline & $\mathrm{p}$ & 0,027 & 0,050 & 0,001 & 0,276 \\
\hline \multirow{2}{*}{ Yasal Meşru Güç } & $\mathrm{r}$ &,$- 313^{*}$ &,$- 215^{*}$ &,$- 289^{*}$ &,$- 186^{*}$ \\
\hline & $\mathrm{p}$ & 0,000 & 0,005 & 0,000 & 0,016 \\
\hline \multirow{2}{*}{ Uzmanlık Gücü } & $\mathrm{r}$ & $-0,125$ &,$- 155^{*}$ & $-0,109$ & 0,075 \\
\hline & $\mathrm{p}$ & 0,109 & 0,045 & 0,161 & 0,334 \\
\hline \multirow{2}{*}{$\begin{array}{l}\text { Karizmatik Beğeniye } \\
\text { Dayalı Güç }\end{array}$} & $\mathrm{r}$ & $-0,036$ & $-0,106$ & 0,006 & 0,076 \\
\hline & $\mathrm{p}$ & 0,641 & 0,173 & 0,943 & 0,332 \\
\hline
\end{tabular}

*: $p<0,05$ (İstatistiksel olarak anlamlı) $\quad r$ : Spearman's Rho Korelasyon Katsayısl

Tablo 7'de ölçekler ve alt boyutları arasındaki ilişki verilmektedir. Uygulanan korelasyon analizleri sonuçları şu şekilde değerlendirilebilir; Savunma sanayinde çalışan kişilerin Örgütsel Sinizm Tutumu ile Örgütsel Güç Kaynağı algıları arasında negatif yönlü \%17,8'lik bir ilişki bulunmaktadır. Bu bulgunun yanısıra, çalışan kişilerin örgütsel sinizm tutumu ile ödüllendirme gücü kaynağı algıları arasında negatif yönlü \%22,5'lik bir ilişki; örgütsel sinizm tutumu ile zorlayıcı güç kaynağı algıları arasında pozitif yönlü $\% 17,1^{\prime}$ lik bir ilişki ve son olarak da örgütsel sinizm tutumu ile yasal güç kaynağı algıları arasında negatif yönlü \%31,3'lik bir ilişki bulunmaktadır.

Yukarıdaki bulgulara ek olarak, Savunma sanayinde çalışan kişilerin bilişsel sinizm boyutu ile örgütsel güç kaynağı algıları arasında negatif yönlü \%20,4'lük bir ilişki; ödüllendirme güç kaynağı algıları ile arasında negatif yönlü \%20,3'lük bir ilişki; yasal güç kaynağı algıları arasında negatif yönlü \%21,5'lik bir ilişki ve son olarak da uzmanlık güç kaynağı algıları arasında negatif yönlü \%15,5’lik bir ilişki bulunmaktadır.

Duyuşsal sinizm boyutu üzerinden değerlendirildiğinde ise, Savunma sanayinde çalışan kişilerin duyuşsal sinizm boyutu ile ödüllendirme güç kaynağı algıları arasında negatif yönlü \%24,1'lik bir ilişki bulunmaktadır. Yanısıra, çalışan kişilerin duyuşsal sinizm boyutu ile zorlayıcı gü̧̈ kaynağı algıları arasında pozitif yönlü \%24,7'lik bir ilişki bulunmakta; yine çalışan kişilerin duyuşsal sinizm boyutu ile yasal güç kaynağı algıları arasında negatif yönlü \%28,9'luk bir ilişki bulunmaktadır.

Son olarak Davranışsal sinizm boyutu ile örgütsel güç kaynakları açısından değerlendirildiğinde ise, Savunma sanayinde çalışan kişilerin Davranışsal Sinizm Boyutu ile Yasal (Meşru) Güç Kaynağı algıları arasında negatif yönlü \%18,6'llk bir ilişki olduğu bulgulanmaktadır.

\section{Sonuç ve Öneriler}

Araştırmada, örgütlerde çalışanların sinik tutuma etki eden faktörleri ortaya koymaya yönelik yürütülen çalışmalardan biri olan örgütlerde algılanan güç kaynakları ile örgütsel sinizm arasındaki ilişki durumu incelenmiştir. Alanyazında, kısıtlı sayıda algılanan güç kaynakları ile örgütsel sinizm arasındaki ilişkinin ortaya koyulmasını amaçlayan araştırmalar bulunmaktadır. Yapılan bu araştırmanın en önemli katkısının, alanyazında var olan çalışmaların aksine farklı bir sektörde bu araştırmanın yapılmış olduğu olarak ifade edilebilir. Bu bağlamda, yapılan araştırmanın Türk Savunma Sanayii'nde çalışanlar özelinde olmasının sektöre katma değer sağlayacağı değerlendirilmektedir.

Araştırma özelinde sonuç incelendiğinde, algılanan güç kaynakları ile örgütsel sinizm arasında ilişkinin varlığı bulgusu alanyazın ile benzerlik taşımakta olup, ters yönlü bir etkileşim söz konusudur. Bu durum sektörel bazda işgören devir oranının diğer sektörlere oranla daha düşük olması ve çalışanların işyerine aidiyet duygusunun yüksek ve yönetici taleplerine itaat etme oranın fazla olmasına bağlı olabilir. Bu çıkarımların ileriki araştırmalarda ele alınması önerilmektedir. 


\section{Erdik Yıldırım - Ş. Erdem Tuzlukaya 11/3 (2019) 2257-2272}

Araştırma sonuçlarına göre, savunma sanayiinde çalışan kişilerin ödüllendirme gücüne ilişkin algısı arttıkça örgütsel sinizm tutumunun azaldığı görülmüştür. Bu nedenle, yöneticilerin ödüllendirme gücüne yönelmeleri durumunda çalışanın sinik tutumdan uzaklaşacağı söylenebilir. Zorlayıcı güç algısı ise, çalışanı sinik tutuma iten etmenlerden biri olup, zorlayıcı güç algısı arttıkça örgütsel sinizm tutumunun arttığ1 görülmüştür. Yöneticinin zorlayıcı gücü kullanması durumunda, çalışanın işlerinin zorlaşacağı, istemeyeceği işler yapmak zorunda kalacağı, iş ortamında ve yapmış olduğu işlerden çalışma ortamındaki olumsuz koşullar sebebiyle mutsuz olacağı söylenebilir. Yasal güç ile örgütsel sinizm arasındaki ilişkiye bakıldığında ise, aralarında saptanan ilişkinin ters olduğu görülmektedir. Sektörel bakış açısıyla, yasal gücün sorgusuz kabul edildiği ve beraberinde itaati getirdiği söylenebilir. Yasal gücün kullanımı ile, çalışan verilen işe odaklanmakta ve yaptığı işe neden yaptığı sorusunu sorgulamadan verilen işi icra ettiği söylenebilir. Bu bağlamda, örgütsel sinizm tutumu ile yasal güç arasında negatif yönlü bir ilişki olup, yasal güç algısı çalışanı sinik tutuma itmekten çok sinik tutumdan uzaklaştıran bir faktöre dönüşmektedir.

Araştırma sonuçlarında, savunma sektöründe zorlayıcı güç kaynağının kullanımı arttıkça çalışanın duyuşsal boyutta sinik tutumun arttığı, diğer boyutlarda anlamlı bir farklılık saptanmadığı görülmektedir. Yazında, genel olarak, güç kaynakları ile örgütsel sinizme yönelik yapılan araştırmalar eğitim sektörü sınırları içerisinde gerçekleşmiştir. Bu bağlamda, bu çalışmanın sonuçları için sektörel karşılaştırma yapılabilmesi söz konusu olmayıp yazından elde edilen sonuç ve/veya bulgular ilk olma özelliği taşımaktadır.

Atmaca'nın (2014) eğitim sektöründe yapmış olduğu araştırmada, okul yöneticilerinin kullandıkları zorlayıcı güç ile öğretmenlerin örgütsel sinizm boyutu yaşama düzeyleri arasında pozitif bir ilişki saptanmıştır. Hoşgörür'ün (2016) yine eğitim sektöründe yapmış olduğu araştırmada, zorlayıcı güç arttıkça örgütsel sinizm boyutları üzerinde düşük ve pozitif yönlü bir ilişki olduğu saptamıştır. Duyuşsal boyutta yazında yer alan sonuçlar ile araştırıcıların sonuçları örtüşmektedir. Bu bilgi ışı̆ıında, savunma sektörü ile eğitim sektörü sonuç ve/veya bulguları birbirini destekler niteliktedir.

Araştırmanın bulgularında, ödüllendirme, uzmanlık ve yasal güç kaynağının çalışan algısında sinik tutumdan uzaklaştıran faktörler olduğu görülmektedir. Ödüllendirme gücü, çalışan üzerinde teşvik etkisi yaratıp motivasyon sağladığı söylenebilir. Bu bağlamda, yöneticinin bu güç kaynağını seçmesi durumunda; çalışanın sadece verilen iş özelinde değil örgütsel bağlamda adil yaklaşımın olduğu bir çalışma ortamının olduğu ve yapmış olduğu işten tatmin olduğu ve aidiyet duygusunun geliştiği görülebilir. Sadece bilişsel ve duyuşsal değişimin gözlendiği ödüllendirme gücü, çalışan zihninde ve duygusal olarak hissettikleriyle sınırlanmakta ve davranışsal boyuta evrilmediği analiz sonucunda ortaya çıkmaktadır. Yöneticiler tarafından çalışanın elde ettiği başarının takdiri, çalışan motivasyonunun sağlanması veya çalışanın işe aidiyet duygusu beslemesi için ödüllendirme gücünün uygulandığı söylenebilir. Ancak yöneticinin kimi zaman çalışanın sessiz kalmasını sağlamak için de bu gücün uygulanabileceği göz ardı edilmemelidir. Demir (2017), yöneticilerin kullandıkları ödüllendirme gücü ile performansı düşüren etkenler arasında negatif yönlü bir ilişki saptamıştır. Bu bağlamda, analiz sonucunda elde edilen veri motivasyon sağlayıcı etken olarak görülmektedir. Hoşgörür (2016), ödüllendirme güç kaynağı ile bilişsel ve duyuşsal sinizm boyutları arasında sırasıyla düşük ve orta düzeyde negatif yönlü bir ilişki saptamıştır. Her iki bulguda saptanan yön, yazın ile örtüşmektedir. Yukarıda yer alan analiz sonuçlarına istinaden, savunma sanayii sektör sonuç ve/veya bulgusu ile eğitim sektörü sonuç ve/veya bulgusu örtüşmektedir.

Savunma sektörü bazında yapılan analizler sonucunda uzmanlık gücünün çalışan nezrindeki algısı, savunma sektöründeki deneyimin sadece kitabi bilgilerle beslenmeyin alan uzmanlığındaki tecrübenin önemini ortaya kovmaktadır. Kritik teknolojilerin ver aldığı bu sektörde, ilgili uzmanlık alanında güçlü bireyler olduğu sürece sektörel bazda ilerlemenin mümkün olabileceğini bu bağlamda, uzmanlığın önemli bir faktör olduğu ortaya kovduğu söylenebilir. Uzmanlık gücünün sadece bilişsel boyutta örgütsel sinizm ile etkileşimde olduğu görülmektedir. Burada, çalışanın zihninde kişinin alanında uzman olduğu düşündüğü ancak duygusal veya davranışsal anlamlı derecede tutumunda bir değişiklik olmadığı söylenebilir. Uzmanlık gücünün kaynağına inildiğinde, uzmanlık gücünün artması çalışanı sinik tutumdan uzaklaştırdığı analiz sonuçlarından elde edilmektedir. Çalışanın; yöneticinin uzmanlığına güvenerek bilgi birikimini kendisi ile paylaşabileceği, olumlu tavsiyeler vererek işi başarıyla gerçekleştirmesini sağlayabileceği, ihtiyaç duyduğu ve kendisinde var olmayan bilgiyi kendisi ile paylaşabileceği gibi bir 


\section{Erdik Yıldırım - Ş. Erdem Tuzlukaya 11/3 (2019) 2257-2272}

algıya sahip olduğu söylenebilir. Hoşgörür (2016), uzmanlık güç kaynağı ile bilişsel sinizm boyutu arasında düşük düzeyde negatif yönlü bir ilişki saptamıştır. Ortaya koyulan araştırma sonucu negatif yönlü olup, yazın ile örtüşmektedir. Savunma sanayii sektörü ile eğitim sektörü sonuç ve/veya bulguları bilişsel sinizm boyutunda birbirini destekler niteliktedir.

Sektörel bağlamda yasal güç algısının örgütsel sinizm tutumunun üç boyutu üzerine etkisinin olduğu görülmektedir. Savunma sektöründe yasal güç, çalışanlar açısından katı hiyerarşik yapının beraberinde getirdiği yaptırımın gücünü temsil etmektedir. Bu güç, beraberinde itaati, yani yönetici taleplerini eksiksiz uygulamayı getirdiği çıkan analiz sonuçlarına göre söylenebilir. Çalışan yaklaşımının itaatkar olmasının, yapılan ise karşı herhangi bir sorgulama sürecine girmeden işin yapıldığına dair bilgi verdiği söylenebilir. Hipotezde ileri sürülen yasal gücün örgütsel sinizmle ilişkisinin varlığı analiz sonuçlarından elde edilmiş olup, saptanan yön ters olarak belirlenmiştir. Analiz sonucuna göre, savunma sektöründe görev alan çalışan algısında eğer yönetici yasal güç uyguluyorsa bu sinik tutumunu azaltan bir faktör olduğu görülmektedir. Burada, yönetici beklentilerinin yasal güç çerçevesinde olduğu bu bağlamda çalışanın sinik tutuma yönelmediği söylenebilir. Ters yönlü etkide ise, katı hiyerarşik yapının bir paydaşı olarak çalışan kişi bu yapıya adapte olup kendisini sinik tutuma iten faktörlerden biri olmaktan çıkmıştır. Yasal güç uygulayan yöneticinin de, hiyerarşik olarak beklenenleri çalışandan istemesi kendisini değerli hissetmesine neden olduğu, beklentilerin ortaya koyularak çalışanın sorumluluklarının olduğu ve görevlerinin olduğu hissini yaratarak çalışan sinik tutumunun azaldığı söylenebilir. Bu bağlamda, savunma sektöründe dozunda uygulanan yasal gücün çalışan algısında pozitif hissiyat yarattığı fikrini desteklemektedir.

Ağçay’a (2015) göre, çalışanların yasal güç algılama düzeyi arttıkça, özdeşleşme tepkisi gösterme düzeyleri de artmaktadır. Yasal güç belirli bir aşamaya kadar çalışanları örgütsel amaçları gerçekleştirmek için hedeflere yöneltmede yeterli olarak görüldüğü, çalışanların özveri göstermesi ve sorumluluk alması gereken durumlarda ihtiyaçları karşılamayacağı ifade edilmektedir. Hoşgörür'e (2016) göre de, yasal güç kaynağı ile duyuşsal sinizm boyutu arasında düşük düzeyde negatif yönlü bir ilişki vardır. Ortaya koyulan araştırma sonucunun yön bulgusu, yazın ile örtüşmektedir. Altınkurt ve diğerlerinin (2014) yapmış olduğu araştırma sonucunda yasal güç kullanım düzeyi arttıkça duyuşsal ve davranışsal boyutta kurumdan uzaklaşma, performansı düşüren etkenlerde ve okula karşı olumsuz tutum alt boyutlarında artış saptanmıştır. Yazındaki mevcut veri, araştırıcıların ortaya koyduğu veriyle - dolaylı (birebir aynı alt boyutlar kapsamında değerlendirilmediği için) olarak - örtüşmemektedir. Yukarıda yer alan sonuçlara istinaden, savunma sanayii sektörü ile eğitim sektörü sonuç ve/veya bulguları yapılan araştırmaya göre farklılık göstermektedir. Yazın ile aynı sonucu destekleyen çalışmaların yanı sıra desteklemeyen sonuçların da varlı̆̆ 1 söz konusudur.

Sektörel açıdan incelendiğinde, karizmatik güç kaynağı ile bilişsel, duyuşsal ve davranışsal boyut arasında herhangi bir etkileşimin olmadığı görülmektedir. Hoşgörür (2016) ise, karizmatik güç kaynağı ile örgütsel sinizm boyutları arasında bilişsel ve davranışsal boyutta düşük düzeyde, duyuşsal boyutta orta düzeyde negatif ilişki saptamıştır. Bu bağlamda, savunma sanayii sektör sonucu ile eğitim sektörü sonucu örtüşmemektedir.

Araştırmanın sınırlılıkları arasında araştırmada kullanılan anketin kartopu modeli uygulanarak toplanması verilebilir. Anketin internet ortamında olması ve bilginin buraya aktarılması anketi cevaplayan katılımclar tarafından güvenli görülemeyebilir ve anket cevaplanma oranı olumsuz etkilenebilir. Diğer bir kısıt olarak, savunma sektörünün konjonktürel durumu ve hassasiyeti sebebiyle anket sorularına ilişkin çekincelerin oluşması ve anketin doldurul(a)maması araştırmanın bir diğer sınırlılığı olabilir. Diğer bir taraftan, anketin internet kullanmayan bir kesime ulaşmaması, internet kullanıcıları ile benzer özellikte olmaları halinde evrenin temsil edilmesinde sorun haline gelebilmektedir (Akalın, 2015). Bu nedenle, yapılacak olan araştırma sosyal ağdaki anketin yayıldığı noktanın internet kullanıcısı olan kesim ile sinirlidır.

Yapılan bu araştırmada desteklenmeyen hipotezler çerçevesinde çalışmaların yapılması ve aralarındaki farklılıkların ortaya koyulmasının alanyazın için önemli olduğu değerlendirilmekte ve yeni çalışmaların yapılması önerilmektedir. Bu araştırmada kullanılan ölçeklerin dışında, güvenilirliği yüksek başka ölçekler kullanılarak veya geliştirilerek yeni araştırmaların gerçekleştirilmesinin sektörel bağlamda karşılaştırma yapma açısından önemli olduğu değerlendirilmektedir. 


\section{Erdik Yıldırım - Ş. Erdem Tuzlukaya 11/3 (2019) 2257-2272}

Diğer bir araştırma konusu olarak, sektörler arası farklılaşma ve farklılıkların kaynağına odaklanılması ve karşılaştırılmalı çalışmalar yapılması önerilmektedir. Sektörler arası farklılaşmanın kullanılan güç kaynaklarının seçiminde önemli olacağı, bu nedenle sektörlere ilişkin çalışan algısının ortaya koyulmasının önemli olduğu ifade edilebilir.

\section{KAYNAKÇA}

Abraham, R. (2000). Organizational Cynicism: Bases and Consequences, Genetic, Social, and General Psychology Monographs, 126(3), 269-292.

Ağçay, F. (2015). Liderin Güç Kaynakları Kullanımı İlişkisi Üzerine Bir Araştırma, Yüksek Lisans Tezi, Dokuz Eylül Üniversitesi, İzmir.

Akar, N.Y. (2010). Psikolojik Sözleşme İhlalleri Bağlamında Örgütsel Sinizm Üzerine Kuramsal Bir Araştırma, Turizmde İnsan Kaynakları Gelişimi Sempozyumu Bildiri Kitabı, 43-60.

Altınkurt, Y., Yılmaz, K., Erol, E. ve Salalı, E.T. (2014). Okul Müdürlerinin Kullandığı Güç Kaynakları İle Öğretmenlerin Örgütsel Sinizm Algıları Arasındaki İlişki, Journal of Teacher Education and Educators, 3 (1), 25-52.

Anderson, C., John, O. P., ve Keltner, D. (2012). The Personal Sense of Power, Journal of Personality, 80 (2), 313-344.

Andersson, L. M. (1996). Employee Cynicism: An Examination Using a Contract Violation Framework. Human Relations, 49(11), 1395-1418.

Atmaca T. (2014) Okul Yöneticilerinin Kullandıkları Güç Türleri ile Öğretmenlerin Yaşadıkları Yıldırma, Örgütsel Bağlllık ve Örgütsel Sinizm Arasındaki İlişki, Yüksek Lisans Tezi, Gazi Üniversitesi Eğitim Bilimleri Enstitüsü, Ankara

Aydın, Ş. ve Coşkun, R. (2007). Örgütsel Güce İlişkin Eleştirel Bir Çözümleme, Akademik İncelemeler Dergisi (AID), 2(2), 97-128.

Baldwin, D.A. (1978). Power and Social Exchange, The American Political Science Review, 72, 1229-1242

Blanca, G. ve Ramona, T. (2016). Change, Resistance to Change and Organizational Cynicism, Studies in Business and Economics, 47-54

Boonstra, J.J. ve Gravenhorst, K.M.B. (1998). Power Dynamics and Organizational Change: A Comparison of Perspectives, European Journal of Work and Organizational Psychology, 97-120.

Brandes, P., ve Das, D. (2006). Locating behavioral cynicism at work: Construct issues and performance implications. In Employee health, coping and methodologies (233-266). Emerald Group Publishing Limited.

Brandes, P., Dharwadkar, R. ve Dean, J.W. (1999). Does Organizational Cynicism Matter? Employee and Supervisor Perspectives On Work Outcomes, Eastern Academy of Management Proceedings, 2 150-153

Brandes, P.M. (1997). Organizational Cynicism: Its Nature, Antecedents, and Consequences. Dissertation of Doctor of Philosophy

Brass, D. J. (2017). Intraorganizational power and dependence. The Blackwell companion to organizations, 138157.

Chiaburu, D. S., Peng, A. C., Oh, I. S., Banks, G. C. ve Lomeli, L. C. (2013). Antecedents and Consequences of Employee Organizational Cynicism: A Meta-Analysis, Journal of Vocational Behavior, 83(2), 181-197.

Cutler, I. (2000). The Cynical Manager. Management Learning, 31(3), 295-312.

Davis, W. D., ve Gardner, W. L. (2004). Perceptions of politics and organizational cynicism: An attributional and leader-member exchange perspective. The leadership quarterly, 15(4), 439-465. 


\section{Erdik Yıldırım - Ş. Erdem Tuzlukaya 11/3 (2019) 2257-2272}

Dean Jr, J. W., Brandes, P., ve Dharwadkar, R. (1998). Organizational cynicism. Academy of Management Review, 23(2), 341-352.

Demir, K. (2017). Okul Yöneticilerinin Kullandıkları Güç Kaynakları ile Öğretmenlerin Sinizm Düzeyleri Arasındaki İlişki, Yüksek Lisans Tezi, İstanbul Sabahattin Zaim Üniversitesi Sosyal Bilimler Enstitüsü

Demir, H., ve Okan, T. (2008). Etkileşimsel ve dönüşümsel liderlik: Bir ölçek geliştirme denemesi. Yönetim, 19(61), 72-90.

Doğan, M. (2014). Karizmatik Liderlik Bağlamında Türk Siyasetçilerinin Değerlendirilmesi, Yüksek Lisans Tezi, Selçuk Üniversitesi, Konya

Doğan, S., ve Uğurlu, C. T. (2014). Okul yöneticilerinin etik liderlik davranişlari ile öğretmenlerin örgütsel sinizm algilari arasindaki ilişki. Gazi Üniversitesi Gazi Eğitim Fakültesi Dergisi, 34(3), 489-516

Fiske, S. T., ve Berdahl, J.(2007). Social power, A. W. Kruglanski ve E. T. Higgins (Eds.), Social psychology: Handbook of basic principles, New York, NY, US: Guilford Press, 678-692

Fleming, P ve Spicer, A. (2003). Working at a cynical distance:Implications for power, subjectivity and resistance, Organization, 10(1), 157-179

French, J.R.P. ve Raven, B. (1959). The Basis of Social Power, Studies in Social Power, 259-269

Goldner, F. H., Ritti, R. R., ve Ference, T. P. (1977). The production of cynical knowledge in organizations. American Sociological Review, 539-551.

Hava, D. ve Kwok-bun, C. (2012). Explaining Charisma: A Macro View Charismatic Leadership in Singapore: Three Extraordinary People, 13-25

Hoşgörür, V. (2016). Relationship between powerbases used by school administrators and teachers' organizational cynicism behaviours. Ponte Academic Journal, 72(5), 51-75.

James, M.S.L. (2005). Antecedents and Consequences of Cynicism in Organizations: An Examination of the Potential Positive and Negative Effects on School Systems, The Florida State University.

Johnson, J.L. ve O'Learly-Kelly, A.M. (2003). The effects of psychological contract breach and organizational cynicism: not all social exchange violations are created equal, Journal of Organizational Behavior, 24, 627-647.

Kalağan, G. ve Güzeller, C.O. (2010). Öğretmenlerin Örgütsel Sinizm Düzeylerinin İncelenmesi, Pamukkale Üniversitesi, Eğitim Fakültesi Dergisi, 27(27), 83-97

Kalağan, G. (2009). Araştırma Görevlilerinin Örgütsel Destek Algıları ile Örgütsel Sinizm Tutumları Arasındaki İlişki, Yüksek Lisans Tezi, Akdeniz Üniversitesi, 2009

Karakostas, A., ve Zizzo, D. J. (2016). Compliance and the power of authority, Journal of Economic Behavior E Organization, 124, 67-80.

Kelman, H. C. (1958). Compliance, identification, and internalization three processes of attitude change. Journal of conflict resolution, 2(1), 51-60.

Köklü, N.(1995). Tutumların Ölçülmesi ve Likert Tipi Ölçeklerde Kullanılması, 81-93

Kurt, İ. (2014). An Exploration of the Relationship Between Organizational Identification and Cynicism: The Role of Authentic Leadership, International Journal of Business and Management Studies, 130-140

Mantere, S. ve Martinsuo, M.(2001). Adopting and Questioning Strategy: Exploring the roles of cynicism and dissent, 17th EGOS - European Group for Organization Studies Colloquium, Lyon, $1-25$

Meydan, C.H. ve Polat, M. (2010). Liderin Güç Kaynakları Üzerine Kültürel Bağlamda Bir Araştırma, Ankara Üniversitesi SBF Dergisi, 123-140 
D. Erdik Yıldırım - Ş. Erdem Tuzlukaya 11/3 (2019) 2257-2272

Meydan, C.H. (2010). Örgüt Kültürü, Örgütsel Güç ve Örgütsel Adalet Algılarının Bireyin İş Tatmini ve Örgüte Bağlllığı Üzerine Etkisi: Kamuda Bir Araştırma, Doktora Tezi, Kara Harp Okulu Savunma Bilimleri Enstitüsü, Ankara

Naus, A.J.A.M.(2007). Organizational Cynicism on The Nature, Antecedents, and Consequences of Employee Cynicism Toward The Employing the Organization, Maastricht: Maastricht University Press.

Özkalp, E., Varoğlu, A., Varoğlu, D., Kırel, A.Ç. ve Acar, P. (2013). Örgütlerde Güç ve Politika, Örgütsel Davranış, Anadolu Üniversitesi Yayın No: 2847, Eskişehir

Palmer, M. ve Hyman, B. (1993). Yönetimde Kadınlar, Rota Yayın

Paulsen,R. (2016). In the mood for obedience: Despair, cynicism, and seduction among employment service employees. Culture and Organization, 24 (5), 365-85

Rose, A., Duschinsky, R.ve Macnaughton, J. (2007). The Art of Medicine: Cynicism as a Strategic Virtue, The Lancet, Cambridge University, Cambridge

Salancik, G.R. ve Pfeffer, J. (1977). Who Gets Power - And How They Hold On It: A Strategic-Contingency Model of Power, American Management Associations, 3-21

Sığrı, Ü. ve Gürbüz, S. (2015). Örgütsel Davranış, İstanbul: Beta Yayınları

Smith R.(2010). Social Work, Risk, Power, Sociological Research Online

Şeşen H. (2011). Örgütlerde Kuralcılık ve Hiyerarşi Eğiliminin Liderlerden Duyulan Tatmine Etkisinde Adalet Algısının Aracılık Rolü, Ç.Ü. Sosyal Bilimler Enstitüsü Dergisi,105-120

Şeşen,H (2010). Öncülleri Ve Sonuçları İle Örgüt İçi Girişimcilik: Türk Savunma Sanayii'nde bir Araştırma. Yayınlanmamış Doktora Tezi

Tokgöz N. ve Yılmaz H.(2008). Örgütsel Sinisizm: Eskişehir ve Alanya'daki Otel İşletmelerinde Bir Uygulama, 283-305

Yukl G. (2013). Leadership in Organizations, New York, Prentice Hall 